\title{
Conformational Dynamics of Strand Register Shifts in DNA G-quadruplexes
}

J. Tassilo Grün, Christopher Hennecker, Dean-Paulos Klötzner, Robert W. Harkness, Irene Bessi, Alexander Heckel, Anthony K. Mittermaier* and Harald Schwalbe*

\section{Supporting Information}

Table of Content

I NMR-data

Figure S1: cMYC: Additional Photocage $\quad$ S2

Figure S2: cMYC: 53 2D-NOESY spectrum $\quad$ S3

Figure S3: cMYC: 33 2D-NOESY spectrum $\quad$ S4

Figure S4: NMR spectra before and initially after triggering folding/refolding S5

Figure S5: cMYC: Folding initiated by photolysis of 3 Photocages $\quad$ S5

Table S2: cMYC: $53 / 33$ chemical shifts $\quad$ S6

Figure S6: cMYC: 53/33 assigned 1D- ${ }^{1} \mathrm{H}$ spectra $\quad$ S6

II CD-data

Figure S7: CD spectra of photocaged cMYC/hTERT

Figure S8: CD melting profiles of photocaged cMYC/hTERT $\quad$ S8

Table S2: Melting temperatures of photocaged cMYC/hTERT

Figure S9: CD spectra of mutant hTERT species $\quad$ S9

III Kinetic analysis

Figure S10: Activation energies from NMR refolding-experiments $\quad$ S10

Global fitting of real-time NMR data $\quad$ S10

IV Thermal melt two-state fitting $\quad$ S11

\begin{tabular}{ll} 
V Isothermal exchange simulations & S13 \\
\hline
\end{tabular}

\begin{tabular}{lll} 
VI $\quad$ Synthesis & S14 \\
\hline
\end{tabular}

\begin{tabular}{lll} 
VII $\quad$ Literature & S17 \\
\hline
\end{tabular} 


\section{NMR-data}

\section{cMYC: Additional Photocage}
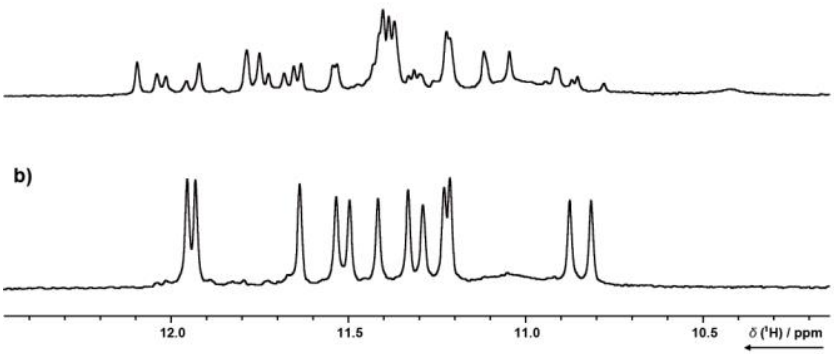

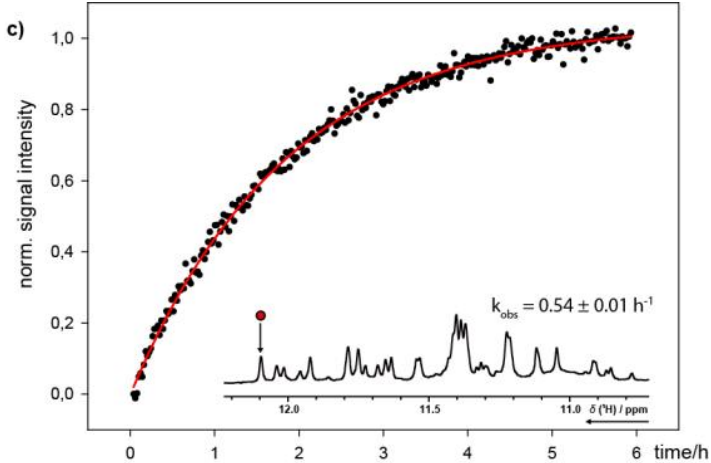

Figure S1. | a) 18-mer cMYC native nucleotide, b) cMYC 5'-shifted (53) with two photocages at position G6 and $\mathrm{G} 18, \mathrm{c})$ Kinetic trace of normalized signal intensity of imino proton from nucleobase G11, shown in red. Data are fitted to a single exponential function.

The observable rate constant for refolding to the native ensemble that can include G18-related conformational polymorphism is slower than the observed rate constant for G-register shift between 5'-shifted (53) and 3'-shifted (33) conformations as expected, since additional conformations can be populated during refolding. 


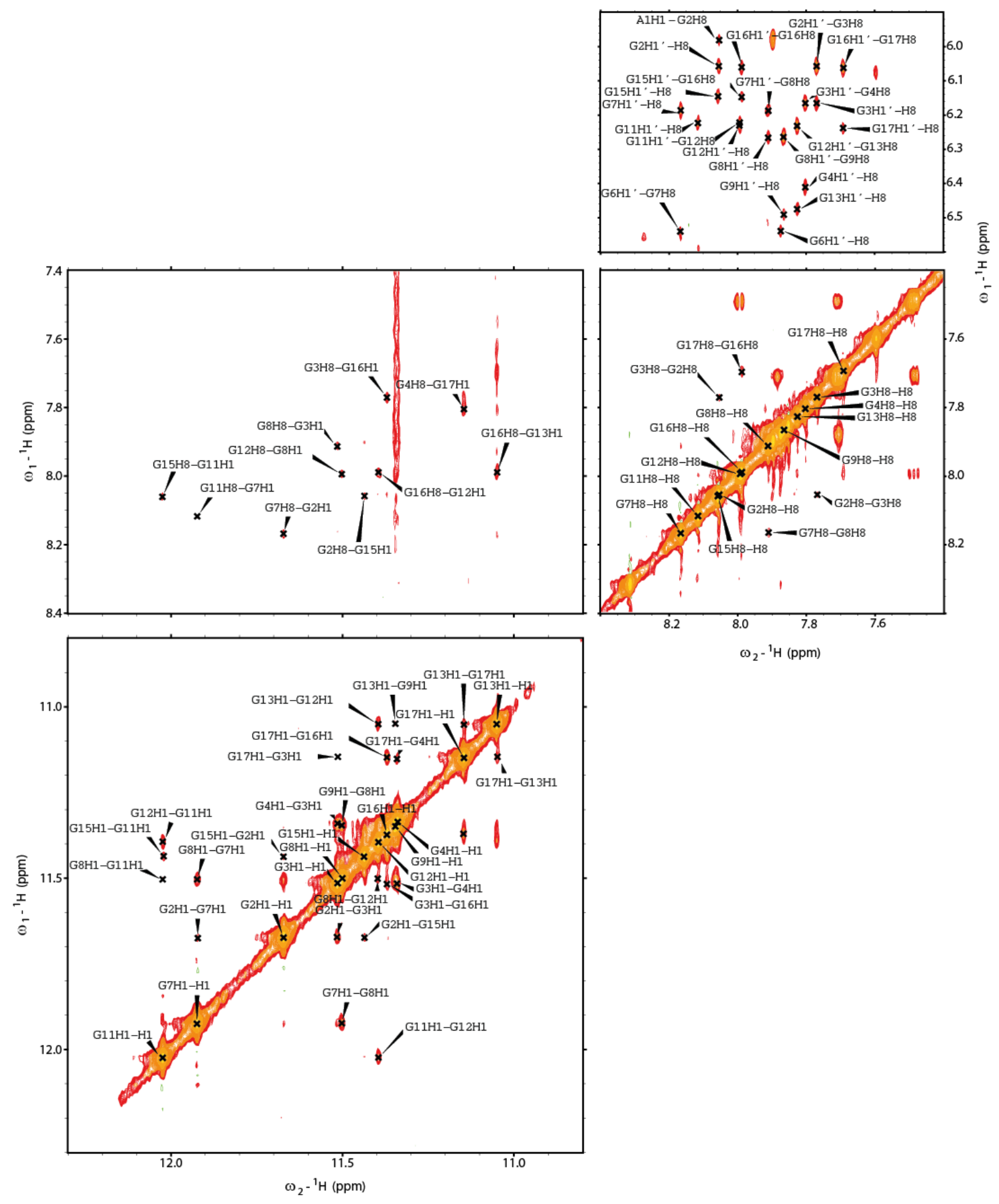

Figure S2. | Characteristic regions of a 2D-NOESY-spectrum of photocaged 5'-shifted cMYC (53) G-quadruplex. The NOESY spectrum was recorded with $8192 \times 1024$ points $(800 \mathrm{MHz}, 298 \mathrm{~K})$ using a pulse-sequence with jumpreturn-echo water-suppression. 

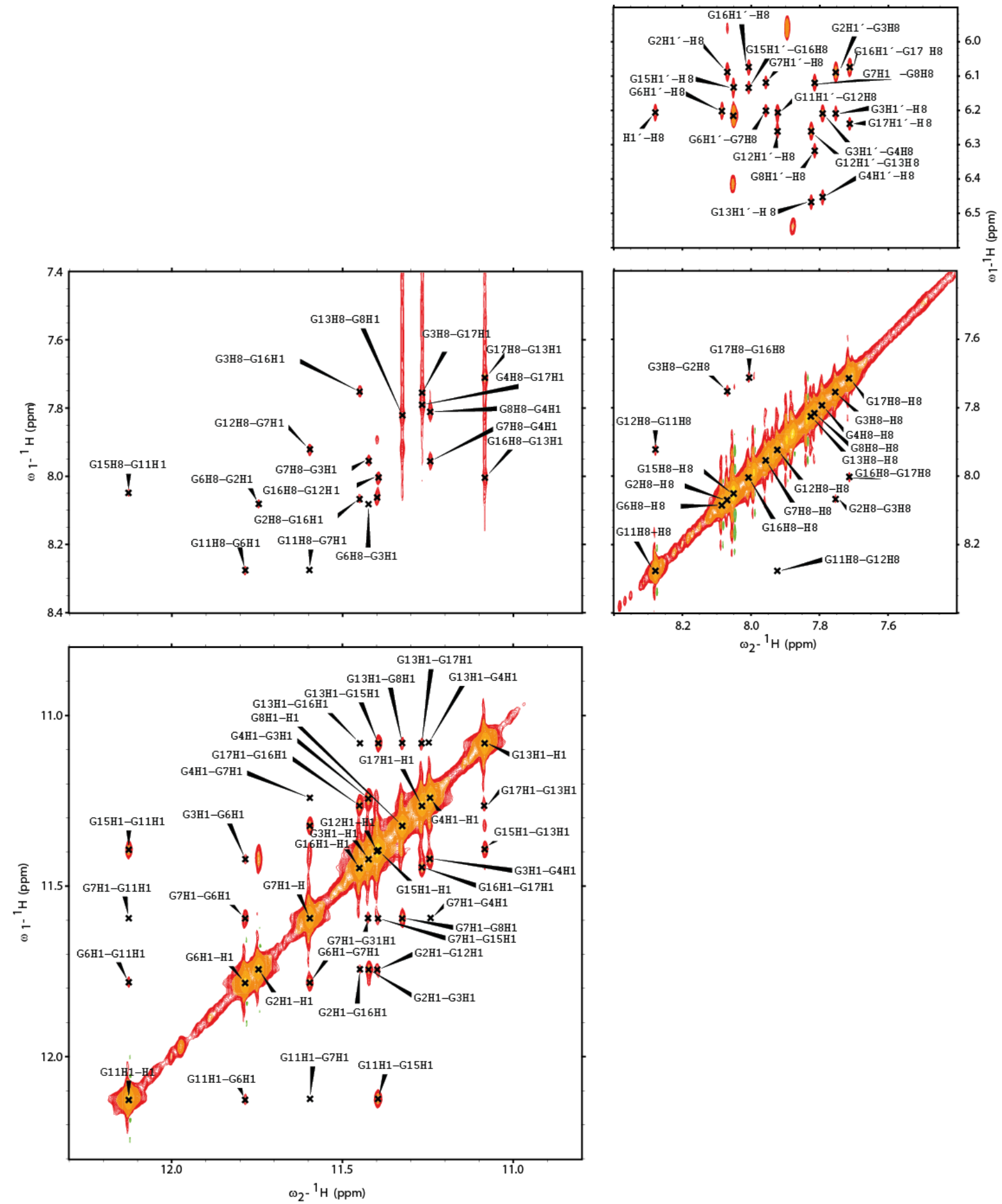

Figure S3. | Characteristic regions of a 2D-NOESY-spectrum of photocaged 3'-shifted cMYC (33) G-quadruplex. The NOESY spectrum was recorded with $8192 \times 1024$ points $(600 \mathrm{MHz}, 298 \mathrm{~K})$ using a pulse-sequence with jumpreturn-echo water-suppression. 


\section{NMR spectra before and initially after triggering folding/refolding}
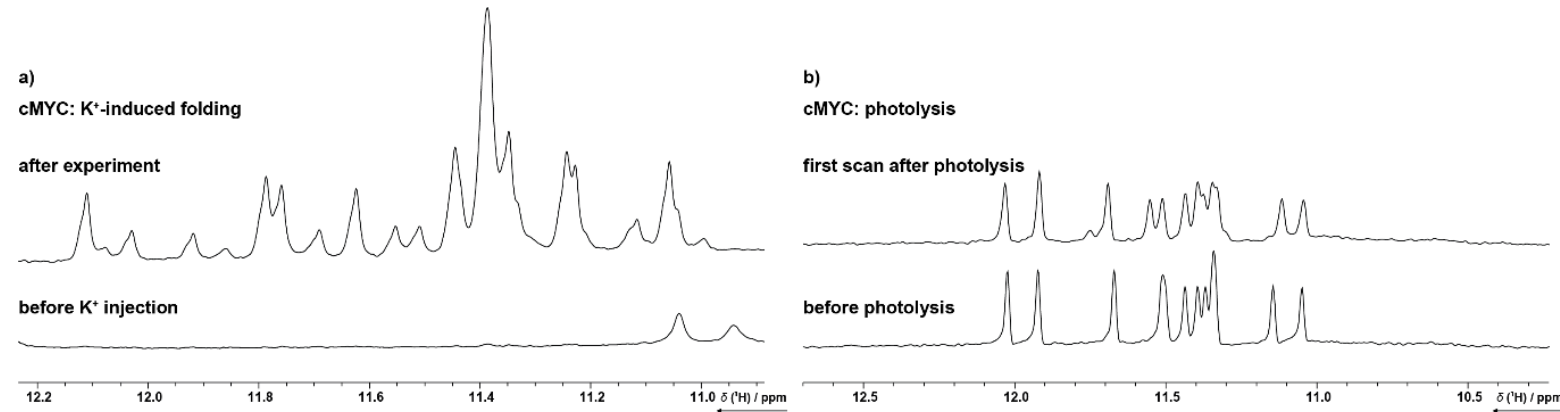

hTERT (parallel): photolysis

d)

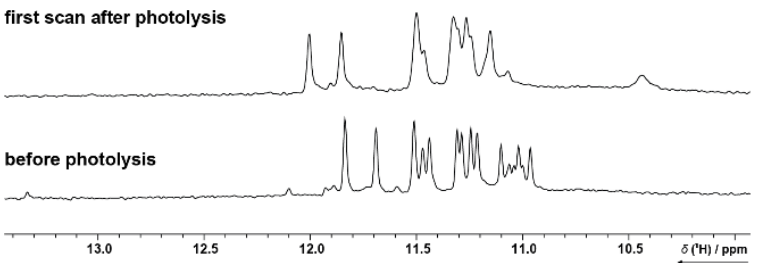

hTERT (hybrid): photolysis

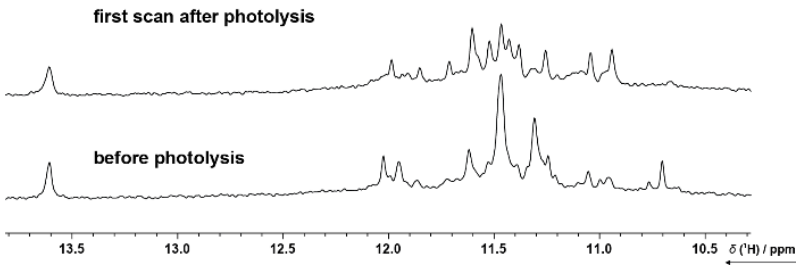

Figure S4. | a) CMYC native nucleotide before and after $\mathrm{K}^{+}$-induced folding. The spectra before $\mathrm{K}^{+}$-injection shows no imino proton signals in the spectral range that is characteristic for G-quadruplex formation b) cMYC 5'-shifted with photocage at position $\mathrm{G} 6$ before and directly after irradiation with laserlight. Some peaks show minor changes in chemical shift, due to the release of the photocage. No line broadening was observed c) hTERT (parallel) with photocages at position G5 and G7 before and directly after irradiation with laserlight. Some peaks show minor changes in chemical shift, due to the release of the photocage. No line broadening was observed. d) hTERT (hybrid) with photocages at position G5 and G7 before and directly after irradiation with laserlight. Some peaks show minor changes in chemical shift, due to the release of the photocage. No line broadening was observed.

\section{cMYC: Folding initiated by photolysis of 3 Photocages}
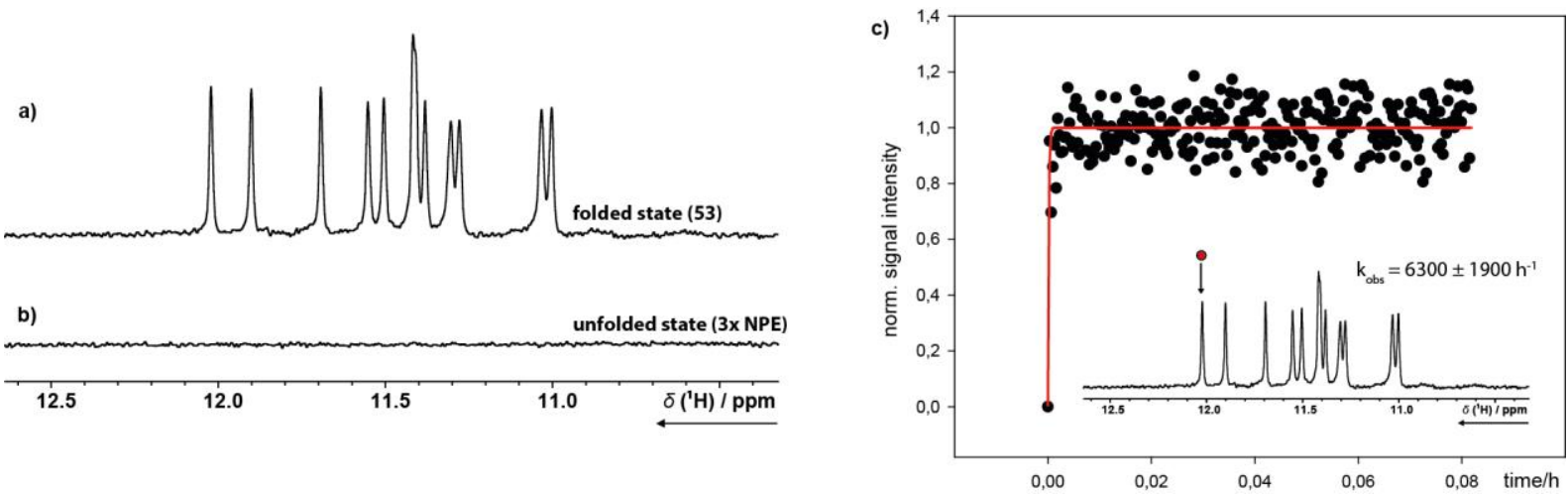

Figure S5. I a) 18-mer cMYC 5'-shifted (53; T6 and T18) folded nucleotide, b) cMYC 5'-shifted with three photocages at position G8, G12 and G16, c) Kinetic trace of normalized signal intensity of imino proton from nucleobase $\mathrm{G} 11$, shown in red. Data are fitted to a single exponential function.

The observable rate constant for folding to the G-quadruplex in pre-equilibrated potassium conditions is faster than the observed rate constant for $\mathrm{K}^{+}$-induced folding and comparable to the folding rates obtained by thermal hysteresis. 
Table S1. | Chemical shifts of assigned proton signals of photocaged cMYC conformations. Data are taken from 2D-NOESY spectra shown in Figures S2 and S3.

\begin{tabular}{c|c|c|c|c}
\multicolumn{2}{c}{} & \multicolumn{2}{c}{ cMYC (53) [ppm] } & \multicolumn{2}{c}{ cMYC (33) ]ppm] } \\
Residue & 11.67 & 8.05 & 11.75 & H8 \\
\hline G2 & 11.52 & 7.77 & 11.42 & 7.75 \\
G3 & 11.34 & 7.80 & 11.24 & 7.79 \\
G4 & - & - & 11.78 & 8.09 \\
G6 & 11.92 & 8.17 & 11.60 & 7.96 \\
G7 & 11.50 & 7.91 & 11.32 & 7.82 \\
G8 & 11.35 & 7.87 & - & - \\
G9 & 12.02 & 8.12 & 12.13 & 8.28 \\
G11 & 11.40 & 8.00 & 11.40 & 7.92 \\
G12 & 11.05 & 7.83 & 11.08 & 7.83 \\
G13 & 11.44 & 8.06 & 11.40 & 8.05 \\
G15 & 11.37 & 7.99 & 11.45 & 8.00 \\
G16 & 11.15 & 7.69 & 11.27 & 7.71 \\
G17 & & & &
\end{tabular}

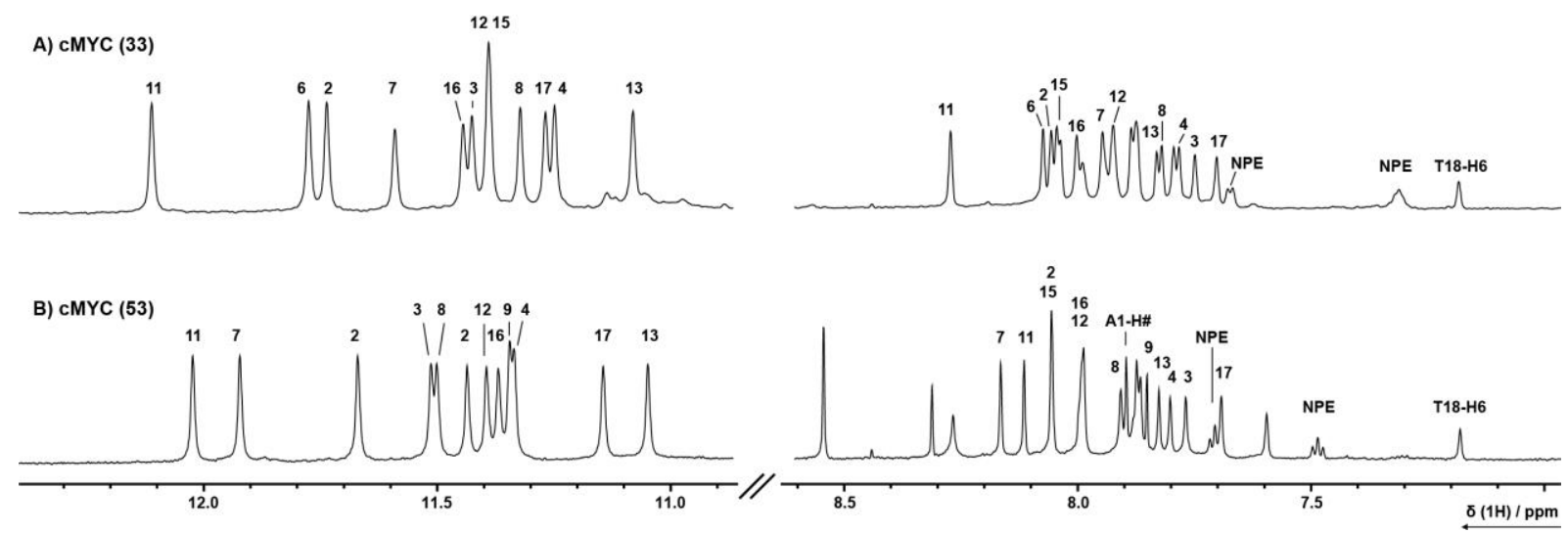

Figure S6. | $1 \mathrm{D}^{1} \mathrm{H}$-NMR spectra showing the imino and aromatic proton regions of photocaged A) CMYC (33) and B) CMYC (53) G-quadruplex. Spectra were recorded using a pulse-sequence with jump-return-echo watersuppressionn (700 MHz, $298 \mathrm{~K})$. 


\section{CD-data}

A)

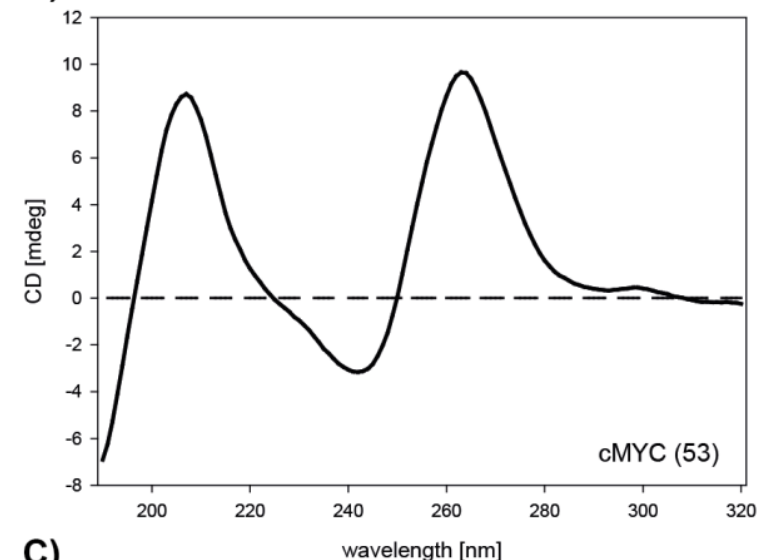

C)

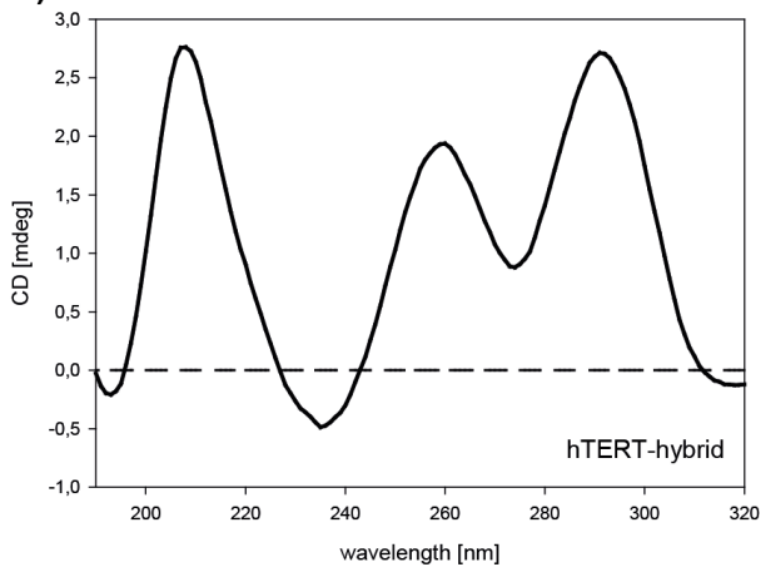

B)

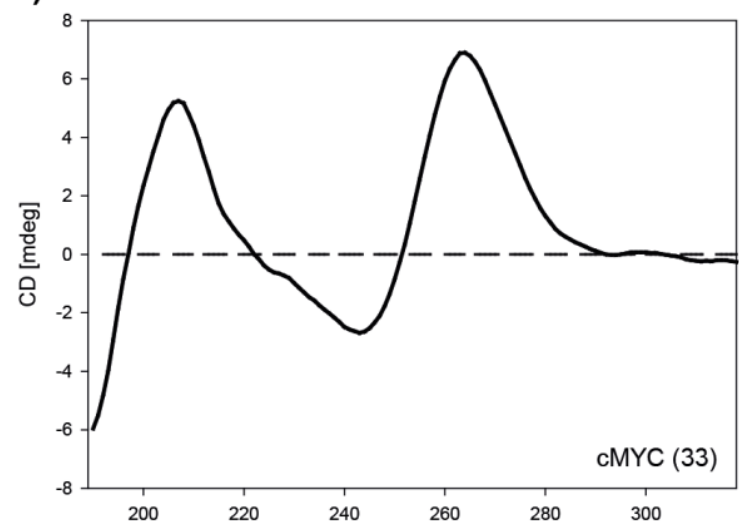

D)

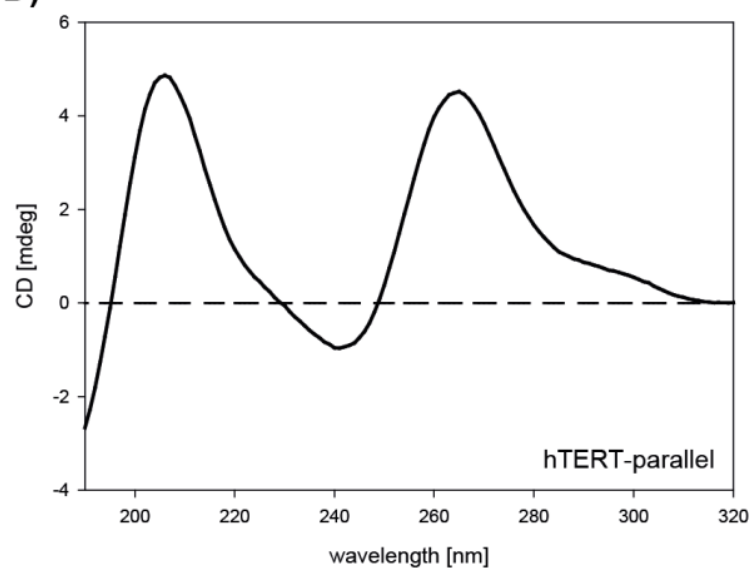

Figure S7. | CD-spectra of investigated photocaged Oligonucleotides. A) CMYC (53, parallel), B) CMYC (33, parallel), C) hTERT (hybrid), D) hTERT (parallel)

All CD-spectra have been recorded on a JASCO spectropolarimeter J-810 at $25^{\circ} \mathrm{C}$. Sample concentrations were $10 \mu \mathrm{M}(\mathrm{cMYC})$ and $7.5 \mu \mathrm{M}$ (hTERT) DNA in $5 \mathrm{mM} \mathrm{K-phosphate} \mathrm{buffer} \mathrm{(pH} \mathrm{7.0).} \mathrm{Spectra} \mathrm{have} \mathrm{been} \mathrm{smoothed} \mathrm{using}$ a Savitzky-Golay filter. 

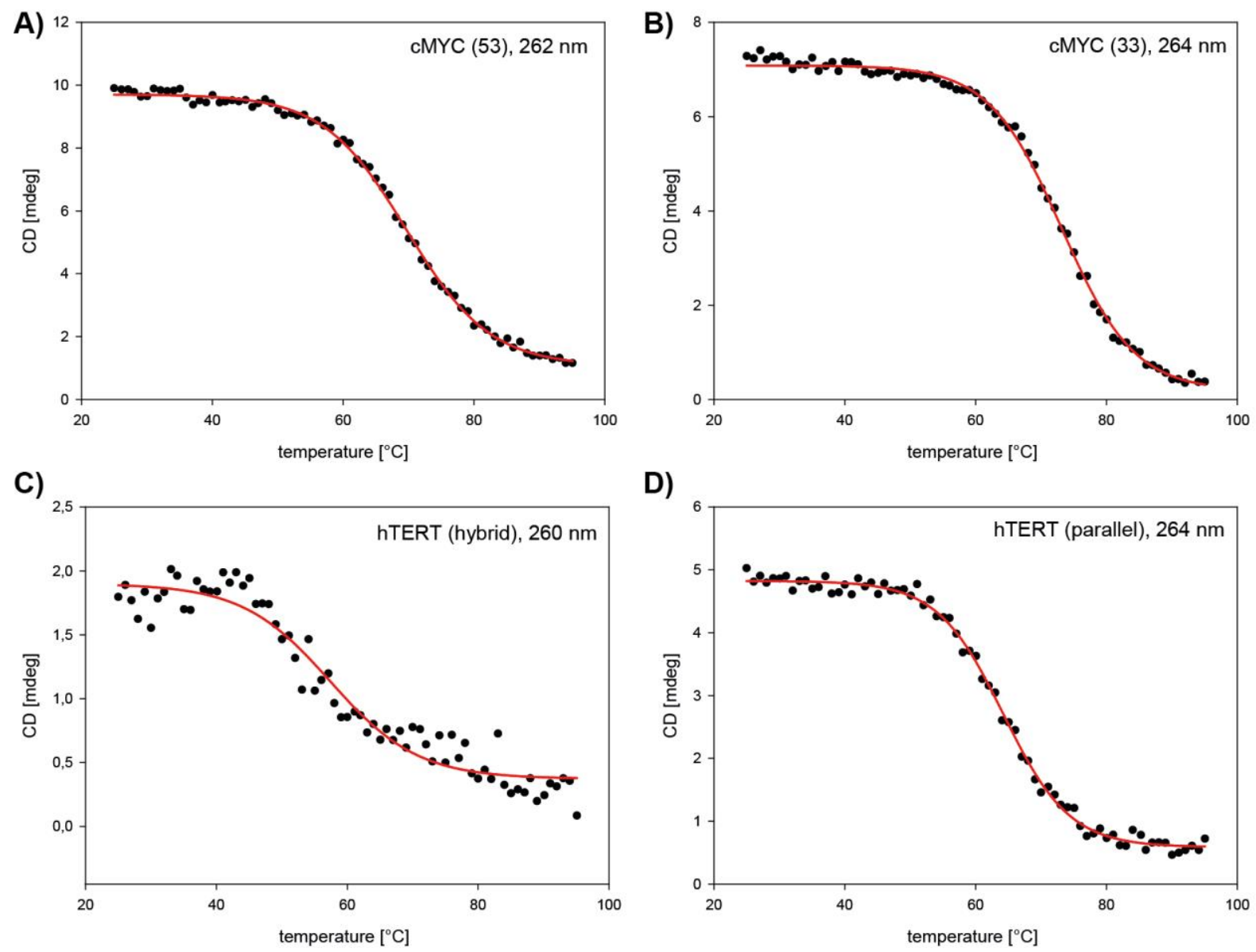

Figure S8. | CD-melting profiles of investigated photocaged Oligonucleotides. A) cMYC (53, parallel), B) cMYC (33, parallel), C) hTERT (hybrid), D) hTERT (parallel)

Melting curves (Figure S8 were recorded between $25^{\circ} \mathrm{C}$ and $95^{\circ} \mathrm{C}$ on respective CD-samples at maximum signal intensity. Melting temperatures (Table S2) have been determined by nonlinear regression using a sigmoidal function (Equation S1). Error estimate comes from error of fitting.

$$
y=y_{0}+\frac{a}{1+e^{-\left(\frac{x-x_{0}}{b}\right)}} \quad \text { (Equation S1) }
$$

Table S2. | Melting temperatures of investigated photocaged oligonucleotides from fitting the CD-melting curves.

\begin{tabular}{|c|c|}
\hline DNA (caged conformation) & $\mathrm{T}_{\mathrm{m}}\left[{ }^{\circ} \mathrm{C}\right]$ \\
\hline cMYC (53) & $69.7 \pm 0.2$ \\
\hline cMYC (33) & $73.2 \pm 0.2$ \\
\hline hTERT (hybrid) & $57.4 \pm 0.9$ \\
\hline hTERT (parallel) & $64.2 \pm 0.2$ \\
\hline
\end{tabular}




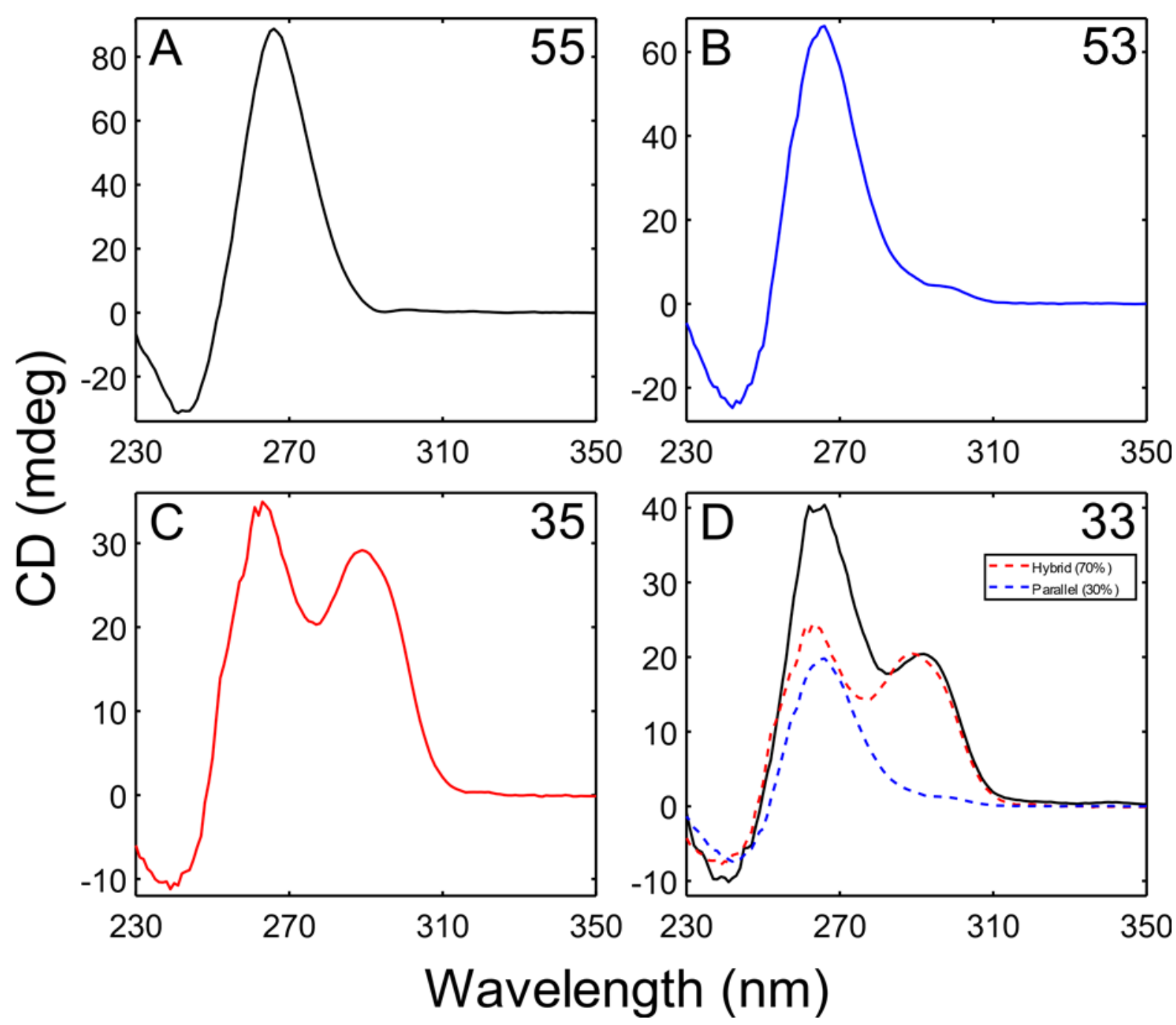

Figure S9. | Circular dichroism spectra of hTERT mutant species. The mutants 53 and 35 have been characterized in the literature as being $>90 \%$ trapped in a single topology (parallel and hybrid, respectively). To determine the topology of the other two mutants (55 and 33) their spectra were deconvoluted into linear combinations of 53 and 35. The mutant 55 was found to be completely parallel while the 33 mutant was found to have a parallel:hybrid ratio of 0.3:0.7. The linear combination (black solid line) is shown as sum of the red and blue dashed lines in (D).

Circular dichroism (CD) experiments were performed using a JASCO J-810 spectropolarimeter in a quartz cuvette with a cell path length of $10 \mathrm{~mm}$. The samples were scanned in triplicate from 330 to $230 \mathrm{~nm}$ at $25^{\circ} \mathrm{C}$. 


\section{Kinetic Analysis}

\section{Activation energies of real-time NMR data}

Activation energy was determined by Arrhenius-plotting according to:

$$
\ln k=\frac{-E_{a}}{R T}+\ln A \quad \text { (Equation S2) }
$$
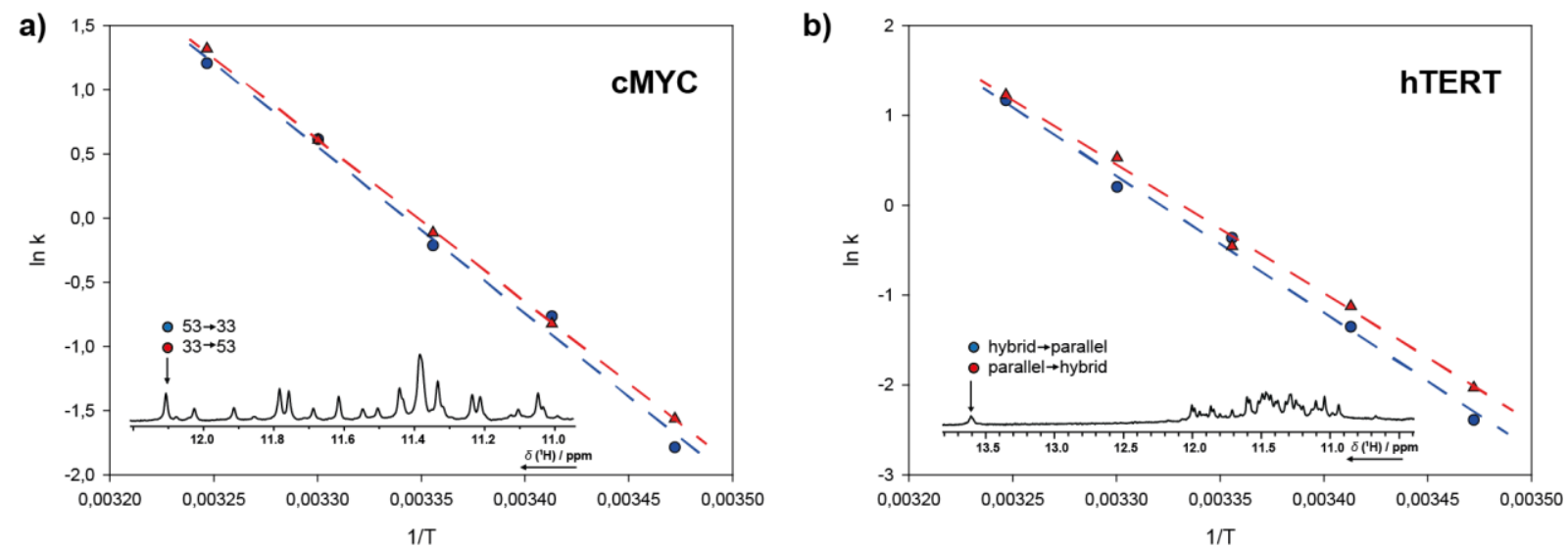

Figure S10. | Arrhenius plot showing the temperature-dependence of rate constants. a) 18-mer cMYC starting with photocaged 5'-shifted (53) conformation shown in blue and starting with photocaged 3'-shifted (33) conformation shown in red, b) 20-mer hTERT starting with photocaged hybrid (35) conformation shown in blue and starting with photocaged parallel (53) conformation shown in red. Data are fitted to a single exponential function and activation energies calculated with linear regression according to equation S2. Standard error for the activation energies is calculated from fitting and is within $5 \%$.

\section{Global Fitting of real-time NMR data}

Observable rate constants were obtained by single-exponential regression of the respective signals.

Optimized Parameters for $\mathrm{k}_{F}, \mathrm{k}_{R F}$ and $\mathrm{k}_{U F}$ were obtained by fitting to the respective models using a python script. We achieved global fitting using differential evolution with global optimization. Differential equations were coupled, assuming a constant overall sum of individual populations. The signals were normalized to the mean equilibrium signal intensities. For hTERT, equilibrium ratios of hybrid:parallel were fixed for normalization. 


\section{Thermal melt two-state fitting}

The TH profiles for each mutant were fit using a two-state model where quadruplex assembly proceeds via an intramolecular folding pathway. The changes in concentration with respect to temperature are

$$
\begin{aligned}
& \frac{d}{d T}[U]=\left(k_{U}[F]-k_{F}[U]\right) \frac{d t}{d T} \\
& \frac{d}{d T}[F]=\left(k_{F}[U]-k_{U}[F]\right) \frac{d t}{d T}
\end{aligned}
$$

where $d t / d T$ is the inverse temperature scan rate. In what follows, the rate constants are assumed to be functions of temperatures, and the concentrations of each series are assumed to be functions of both temperature and scan rate. The temperature dependences of the rate constants are given by

$$
k(T)=k_{0} e^{\frac{E a}{R} *\left(\frac{1}{T_{r e f}}-\frac{1}{T}\right)}
$$

Where $k_{0}$ is the rate constant at the reference temperature $T_{\text {ref }}$ and $E_{a}$ is the activation energy. In the two-state fits of the TH profiles Eqs. 1-2 were numerically integrated using the ordinary differential equation (ODE) solvers in MATLAB to obtain concentrations of both the folded and unfolded forms as a function of temperature. The concentrations obtained were converted to fraction unfolded and folded respectively using

$$
\begin{aligned}
C_{T} & =[F]+[U] \\
\theta_{F} & =\frac{[F]}{C_{T}} \\
\theta_{U} & =\frac{[U]}{C_{T}}
\end{aligned}
$$

Which permitted calculation of the thermal absorbance profiles as

$$
A(T)=A_{F}(T) \theta_{F}(T)+A_{U}(T) \theta_{U}(T)
$$

Where $A_{F}(T)$ and $A_{U}(T)$ are the linear folded and unfolded absorbance baselines optimized in the fitting. The sets of TH profiles were fit by varying the kinetic parameters to minimize the RSS between the experimental and fitted absorbance data according to

$$
R S S=\sum_{j=1}^{N} \sum_{k} \frac{\left(A_{j}^{\exp }\left(T_{k}\right)-A_{j}^{\text {calc }}\left(T_{k}, \xi\right)\right)^{2}}{k}
$$

Where $A_{j}^{\text {exp }}\left(T_{k}\right)$ and $A_{j}^{\text {calc }}\left(T_{k}\right)$ are the $j^{\text {th }}$ experimental and fitted absorbance profiles respectively, $T_{k}$ is the $k^{\text {th }}$ experimental temperature, $\xi=\left[k_{F}, k_{U}, E_{F}, E_{U}\right]$ are the rate constants at the reference temperature and activation energies governing assembly and disassembly of the GQ.

\section{Statistical Analysis of Errors for TH Fitting}

Errors in the fit parameters for TH profiles were calculated using the variance-covariance matrix ${ }^{1}$ given by

$$
V=\frac{R S S}{D F} *\left(X W X^{\prime}\right)^{-1}
$$

Where RSS is the residual sum of squared differences between experimental and fitted data points, $D F$ is the degrees of freedom of the fit ( $N$ data points minus $\Phi$ parameters of the fit) and $W$ is a diagonal matrix of fitting weights, in this case all taken to be identically 1. $X$ is a matrix of the first derivatives of the differences between the experimental and calculated data points $\left(A^{\exp }\right.$ and $\left.A^{\text {calc }}\right)$, with respect to increments in each of the adjustable parameters $\left(\Phi_{i}\right)$. The element corresponding to the $i^{\text {th }}$ adjustable parameter and $j^{\text {th }}$ data point is thus

$$
X_{i j}=\frac{\partial\left(A_{j}^{e x p}-A_{j}^{c a l c}\right)}{\partial \Phi_{i}} \equiv \frac{\partial \alpha_{j}}{\partial \Phi_{i}}
$$

where $A_{j}^{\text {calc }}$ is evaluated at the optimized set of parameters, $\Phi$. The elements were evaluated numerically according to

$$
X_{i j}=\frac{\partial\left(A_{j}^{\text {calc }}(-\Delta)-A_{j}^{\text {calc }}(+\Delta)\right)}{2 \Delta}
$$


Where $A_{j}^{\text {calc }}( \pm \Delta)$ is the $j^{\text {th }}$ data point calculated with all adjustable parameters set to their optimized values except, for the $i^{\text {th }}$ parameter, which is incremented by $\pm \Delta$. For a fit with $N$ data points and $M$ adjustable parameters this gives

$$
X=\left[\begin{array}{ccc}
\frac{\partial \alpha_{1}}{\partial \Phi_{1}} & \cdots & \frac{\partial \alpha_{N}}{\partial \Phi_{1}} \\
\vdots & \ddots & \vdots \\
\frac{\partial \alpha_{1}}{\partial \Phi_{M}} & \cdots & \frac{\partial \alpha_{N}}{\partial \Phi_{M}}
\end{array}\right]
$$

The diagonal elements in $V$ are the variances of the optimized fit parameters, while the off-diagonal elements are the covariances between the errors of the optimized parameters. Errors in fitted parameters were taken as the square root of the variances. 


\section{$\underline{V}$ Isothermal exchange simulations}

The kinetic parameters obtained from the independent two state fits of the TH profiles for each of the mutants were used to simulate isothermal exchange between GR isomers. Since the CMYC GQ is able to exchange between two different isomers the following equations describe this process in terms of a model where exchange can only happen exclusively through the unfolded state.

$$
\begin{aligned}
& \frac{d}{d T}[U]=k_{U_{53}}\left[F_{53}\right]+k_{U_{33}}\left[F_{33}\right]-\left(k_{F_{53}}+k_{F_{33}}\right)[U] \\
& \frac{d}{d t}\left[F_{53}\right]=k_{F_{53}}[U]-k_{U_{53}}\left[F_{53}\right] \\
& \frac{d}{d t}\left[F_{33}\right]=k_{F_{33}}[U]-k_{U_{33}}\left[F_{33}\right]
\end{aligned}
$$

Isotherms were simulated by numerically integrating the above rate equations, where the initial starting conditions were completely folded in either the 53 or 33 states. These simulations were carried out at the same temperatures used for NMR refolding experiments and fit to equations 3 and 16 to solve for both the apparent rate of exchange $\left(k_{a p p}\right)$ and the apparent activation energy $\left(E_{a p p}\right)$ which allowed direct comparisons to the experimental data.

$$
\frac{d}{d t}[F 53]=y 0+a *\left(1-\exp \left(-k_{a p p} * x\right)\right)
$$

In the case of hTERT, this GQ can adopt four different isomers which leads to the following rate equations 17-21. These equations account for each of the folding rates of the individual species. To compare to NMR experiments initial conditions of completely folded in either the 53 or 35 states were simulated, and the concentration of the hybrid topology was calculated using equation 22. Once again isotherms were simulated at the same temperatures used for NMR refolding experiments and fit to equations 3 and 16 to solve for both the apparent rate of exchange $\left(k_{a p p}\right)$ and the apparent activation energy $\left(E_{a p p}\right)$.

$$
\begin{gathered}
\frac{d}{d T}[U]=k_{U_{55}}\left[F_{55}\right]+k_{U_{53}}\left[F_{53}\right]+k_{U_{35}}\left[F_{35}\right]+k_{U_{33}}\left[F_{33}\right]-\left(k_{F_{55}}+k_{F_{53}}+k_{F_{35}}+k_{F_{33}}\right)[U] \\
\frac{d}{d t}\left[F_{55}\right]=k_{F_{55}}[U]-k_{U_{55}}\left[F_{55}\right] \\
\frac{d}{d t}\left[F_{53}\right]=k_{F_{53}}[U]-k_{U_{53}}\left[F_{53}\right] \\
\frac{d}{d t}\left[F_{35}\right]=k_{F_{35}}[U]-k_{U_{35}}\left[F_{35}\right] \\
\frac{d}{d t}\left[F_{33}\right]=k_{F_{33}}[U]-k_{U_{33}}\left[F_{33}\right] \\
\quad\left[F_{\text {Hybrid }}\right]_{t}=\left[F_{35}\right]_{t}+0.7 *\left[F_{33}\right]_{t}
\end{gathered}
$$

\section{Statistical Analysis of Isothermal Exchange Parameters}

Errors for the fitted values of $k_{a p p}$ and $E_{a p p}$ in the isothermal exchange simulations were calculated using Monte Carlo error propagation. ${ }^{1}$ Latin Hypercube Sampling was used to generate 1000 sets of random parameters within the error range found from TH fitting. These sets of parameters were then used to calculate 1000 values of $k_{a p p}$ and $E_{a p p}$, the error for these parameters was taken as the square root of the variance of these set 


\section{Synthesis}

The reactions presented were performed under argon atmosphere using dry solvents. NMR analysis of new compounds were performed on Bruker AV500 and DRX600 MHz spectrometers. Assignment of proton chemical shifts was done via ${ }^{1} \mathrm{H}-{ }^{1} \mathrm{H}$-COSY experiments. For flash chromatography silica gel 60 by Macherey-Nagel was used.

Compound 1 was prepared according to Mayer et al. ${ }^{2}$

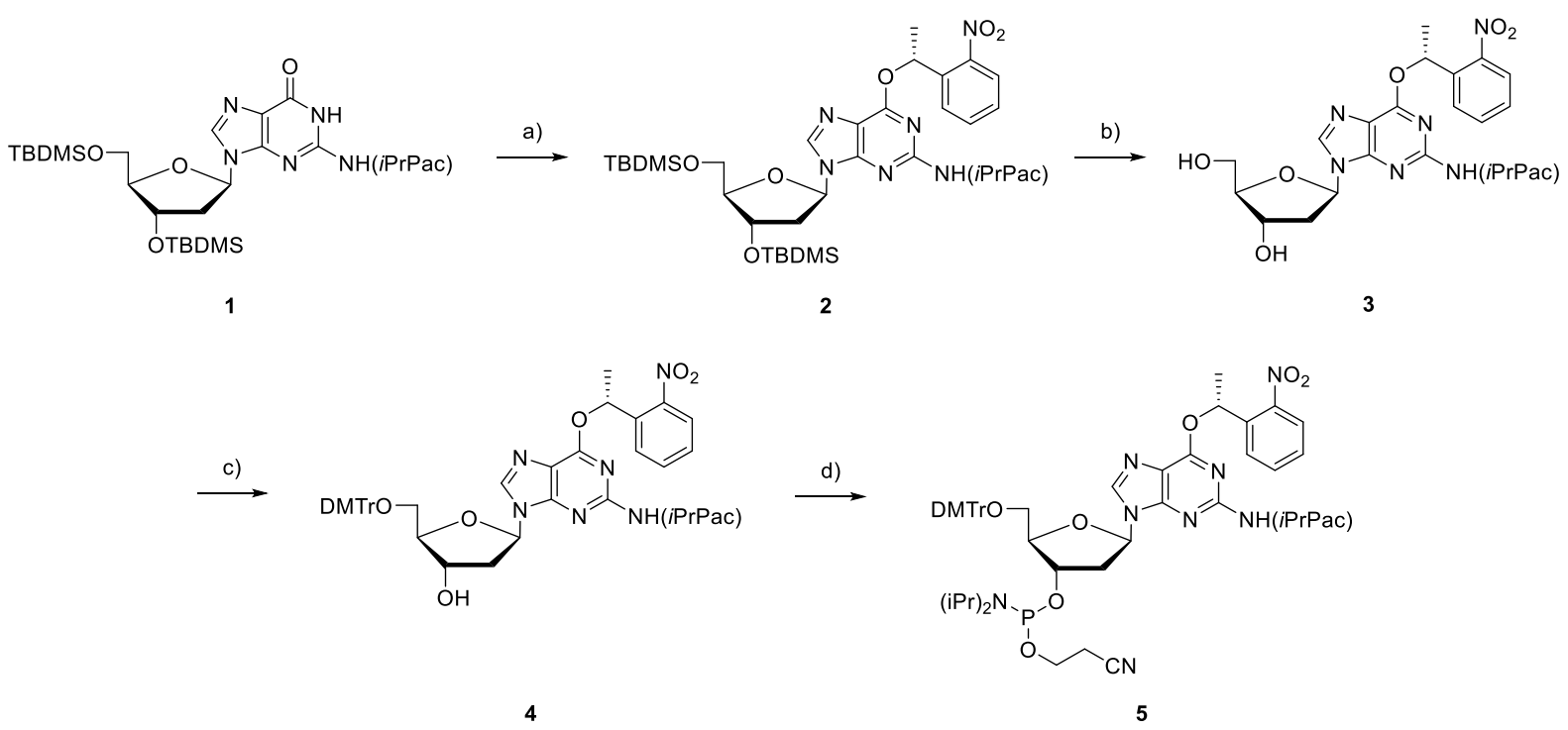

Scheme S1. I Synthesis of $(R)-\mathrm{NPE}_{\mathrm{dG}}$ phosphoramidite. a) (S)-1-(2-Nitrophenyl)ethanol (prepared as described in the literature ${ }^{3}$ ), $\mathrm{PPh}_{3}$, DEAD (40 wt\% in toluene), THF, 65\%; b) TBAF, HOAc, THF, 78\%; c) 4,4'-Dimethoxytrityl chloride, pyridine, 82\%; 2-Cyanoethoxy- $N, N$-diisopropylaminochlorophosphine, (iPr) ${ }_{2} \mathrm{NEt}, \mathrm{DCM}, 71 \%$.

\section{Synthesis of compound 2:}

$4.09 \mathrm{~g}$ DEAD solution (40 wt\% in toluene, $9.39 \mathrm{mmol}, 1.5 \mathrm{eq}$.) was added dropwise to a solution of $4.21 \mathrm{~g}$ of compound 1 (6.26 mmol, 1 eq.), $1.15 \mathrm{~g}(S)$-1-(2-nitrophenyl)ethanol (6.89 mmol, 1.1 eq.) and $2.46 \mathrm{~g} \mathrm{PPh}_{3}$ (9.39 mmol, 1.5 eq.) in $30 \mathrm{~mL}$ dry THF. The solution was stirred for 60 minutes at room temperature, concentrated and diluted with $200 \mathrm{~mL} \mathrm{DCM}$ and $200 \mathrm{~mL}$ brine. The aqueous layer was extracted with $100 \mathrm{~mL} \mathrm{DCM} \mathrm{(2x).} \mathrm{The} \mathrm{combined}$ organic phases were dried over $\mathrm{MgSO}_{4}$. The solvent was evaporated and the residue purified via column chromatography (cyclohexane/EtOAc $3: 1 \rightarrow 1: 1$ ) to give 2 as a yellowish foam.

Yield: $3.33 \mathrm{~g}(65 \%)$

$\underline{1 \mathrm{H}-N M R}\left(600 \mathrm{MHz}, \mathrm{DMSO}-\mathrm{d}_{6}\right): \delta=10.24(\mathrm{~s}, 1 \mathrm{H}, \mathrm{NH}), 8.41\left(\mathrm{~s}, 1 \mathrm{H}, \mathrm{H}_{\mathrm{ar}}\right), 8.01\left(\mathrm{~d}, J=6 \mathrm{~Hz}, 1 \mathrm{H}, \mathrm{H}_{\mathrm{ar}}\right), 7.81$ (d, $J=12$ $\left.\mathrm{Hz}, 1 \mathrm{H}, \mathrm{H}_{\mathrm{ar}}\right), 7.73\left(\mathrm{t}, J=12 \mathrm{~Hz}, 1 \mathrm{H}, \mathrm{H}_{\mathrm{ar}}\right), 7.54\left(\mathrm{t}, J=6 \mathrm{~Hz}, 1 \mathrm{H}, \mathrm{H}_{\mathrm{ar}}\right), 7.14\left(\mathrm{~d}, J=6 \mathrm{~Hz}, 2 \mathrm{H}, \mathrm{H}_{\mathrm{ar}}\right), 6.85-6.82(\mathrm{~m}, 3 \mathrm{H}$, $\mathrm{H}_{\mathrm{ar}}, \mathrm{CH}$ NPE), 6.29 (t, $\left.J=6 \mathrm{~Hz}, 1 \mathrm{H}, 1^{\prime}-\mathrm{H}\right), 4.86-4.80\left(\mathrm{~m}, 2 \mathrm{H}, \mathrm{CH}_{2} \mathrm{O}\right.$ iPrPac), $4.59\left(\mathrm{~s}, 1 \mathrm{H}, 3^{\prime}-\mathrm{H}\right), 3.84-3.82\left(\mathrm{~m}, 1 \mathrm{H}, 4^{\prime}-\right.$ H), 3.77-3.74 (m, 1H, 5'-H), 3.65-3.62 (m, 1H, 5'-H), 2.93-2.89 (m, 1H, 2'-H), 2.84-2.80 (m, 1H, CH iPrPac), 2.29$2.27\left(\mathrm{~m}, 1 \mathrm{H}, 2^{\prime}-\mathrm{H}\right), 1.80\left(\mathrm{~d}, 3 \mathrm{H}, \mathrm{OCHCH}_{3}\right), 1.16\left(\mathrm{~d}, J=6 \mathrm{~Hz}, 6 \mathrm{H}, \mathrm{CH}_{3} \operatorname{PrPac}\right), 0.86\left(\mathrm{~s}, 9 \mathrm{H}, \operatorname{SiC}\left(\mathrm{CH}_{3}\right)_{3}\right), 0.82(\mathrm{~s}, 9 \mathrm{H}$, $\left.\mathrm{SiC}\left(\mathrm{CH}_{3}\right)_{3}\right), 0.07\left(\mathrm{~d}, J=6 \mathrm{~Hz}, 6 \mathrm{H}, \mathrm{Si}\left(\mathrm{CH}_{3}\right)_{2}\right), 0.02\left(\mathrm{~d}, J=6 \mathrm{~Hz}, 6 \mathrm{H}, \mathrm{SiC}\left(\mathrm{CH}_{3}\right)_{2}\right)$ ppm.

$\underline{{ }^{13} \mathrm{C}-\mathrm{NMR}}\left(150.9 \mathrm{MHz}, \mathrm{DMSO}-\mathrm{d}_{6}\right): \delta=158.92,155.88,152.77,151.19,147.68,141.68,140.88,137.01,134.08$, $129.00,127.19,127.01,124.30,117.72,114.30,87.36,83.49,72.01,70.33,67.27,62.73,32.55,25.67,25.60$, 24.02, 21.69, 17.87, 17.59, -4.87, -5.04, -5.60, -5.62 ppm.

MALDI-HRMS: $m / z$ calcd. for $\mathrm{C}_{41} \mathrm{H}_{60} \mathrm{~N}_{6} \mathrm{O}_{8} \mathrm{Si}_{2}[\mathrm{M}+\mathrm{Na}]^{+} 844.39369$, found 844.39351 . 


\section{Synthesis of compound 3 :}

$3.3 \mathrm{~g}$ of compound $2(4.02 \mathrm{mmol}, 1$ eq.) were dissolved in $40 \mathrm{~mL}$ dry THF. $1.38 \mathrm{~mL}$ Acetic acid $(24.11 \mathrm{mmol}, 6 \mathrm{eq}$.) and $12.06 \mathrm{~mL}$ TBAF solution (1 M in THF, $12.06 \mathrm{mmol}, 3$ eq.) were added. The reaction mixture was stirred at room temperature for 23 hours. The solvent was evaporated and the residue purified via column chromatography $(\mathrm{DCM} / \mathrm{MeOH}$ 99:1 $\rightarrow$ 92:8) to give $\mathbf{3}$ as a yellowish foam.

Yield: $1.87 \mathrm{~g}(78 \%)$

1H-NMR (600 MHz, DMSO-d $): \delta=10.27(\mathrm{~s}, 1 \mathrm{H}, \mathrm{NH}), 8.47\left(\mathrm{~s}, 1 \mathrm{H}, \mathrm{H}_{\mathrm{ar}}\right.$ ), $8.01(\mathrm{~d}, J=12 \mathrm{~Hz}, 1 \mathrm{H}, \mathrm{Har}), 7.81$ (d, $J=12$ $\left.\mathrm{Hz}, 1 \mathrm{H}, \mathrm{H}_{\mathrm{ar}}\right), 7.74\left(\mathrm{t}, J=6 \mathrm{~Hz}, 1 \mathrm{H}, \mathrm{H}_{\mathrm{ar}}\right), 7.54\left(\mathrm{t}, J=6 \mathrm{~Hz}, 1 \mathrm{H}, \mathrm{H}_{\mathrm{ar}}\right), 7.15\left(\mathrm{~d}, J=12 \mathrm{~Hz}, 2 \mathrm{H}, \mathrm{H}_{\mathrm{ar}}\right), 6.86-6.82(\mathrm{~m}, 3 \mathrm{H}$, $\mathrm{H}_{\mathrm{ar}}, \mathrm{CH}$ NPE), $6.31\left(\mathrm{t}, J=6 \mathrm{~Hz}, 1 \mathrm{H}, 1^{\prime}-\mathrm{H}\right), 5.30\left(\mathrm{~s}, 1 \mathrm{H}, 3^{\prime}-\mathrm{OH}\right), 4.90-4.83\left(\mathrm{~m}, 3 \mathrm{H}, 5^{\prime}-\mathrm{OH}, \mathrm{CH}_{2} \mathrm{O} \operatorname{PrPac}\right), 4.40(\mathrm{~s}, 1 \mathrm{H}$, 3'-H), 3.85-3.84 (m, 1H, 4'-H), 3.59-3.57 (m, 1H, 5'-H), 3.51-3.49 (m, 1H, 5'-H), 2.82 (sep, J $=6 \mathrm{~Hz}, 1 \mathrm{H}, \mathrm{CH}$ PrPac), $2.70\left(\mathrm{q}, J=6 \mathrm{~Hz}, 1 \mathrm{H}, 2^{\prime}-\mathrm{H}\right), 2.28-2.27\left(\mathrm{~m}, 1 \mathrm{H}, 2^{\prime}-\mathrm{H}\right), 1.80\left(\mathrm{~d}, J=6 \mathrm{~Hz}, 3 \mathrm{H}, \mathrm{OCHCH}_{3}\right), 1.17\left(\mathrm{~d}, J=6 \mathrm{~Hz}, 6 \mathrm{H}, \mathrm{CH}_{3}\right.$ iPrPac) ppm.

${ }^{13} \mathrm{C}-\mathrm{NMR}(150.9 \mathrm{MHz}$, DMSO-d $): \delta=167.25,158.89,155.88,152.88,151.28,147.64,141.48,140.90,137.06$, $134.13,129.01,127.18,127.07,124.35,117.49,114.33,87.91,83.35,70.62,70.37,67.34,61.55,40.06,32.55$, 24.05, $21.70 \mathrm{ppm}$.

MALDI-HRMS: $\mathrm{m} / z$ calcd. for $\mathrm{C}_{29} \mathrm{H}_{32} \mathrm{~N}_{6} \mathrm{O}_{8}[\mathrm{M}+\mathrm{K}]^{+} 631.19132$, found 631.19102 .

\section{Synthesis of compound 4:}

$1.87 \mathrm{~g}$ of compound 3 (3.12 mmol, 1 eq.) were dissolved in $50 \mathrm{~mL}$ dry pyridine. $1.28 \mathrm{~g}$ 4,4'-Dimethoxytrityl chloride $(3.79 \mathrm{mmol}, 1.2 \mathrm{eq}$.) were added in portions. The reaction mixture was stirred at room temperature for 3 hours. The solvent was evaporated and the residue diluted with $200 \mathrm{~mL}$ DCM and washed with $200 \mathrm{~mL}$ saturated sodium bicarbonate solution. The aqueous layer was extracted with $100 \mathrm{~mL}$ DCM $(2 \mathrm{x})$. The combined organic layers were dried over $\mathrm{MgSO}_{4}$ and evaporated. The residue was purified via column chromatography $\left(\mathrm{DCM} / \mathrm{MeOH} / \mathrm{Et}_{3} \mathrm{~N}\right.$ 98:1:1) to give $\mathbf{4}$ as a yellowish foam.

Yield: $2.3 \mathrm{~g}(82 \%)$

1H-NMR (500 MHz, DMSO-d $): \delta=10.19(\mathrm{~s}, 1 \mathrm{H}, \mathrm{NH}), 8.38(\mathrm{~s}, 1 \mathrm{H}, \mathrm{Har}), 8.00(\mathrm{~d}, J=10 \mathrm{~Hz}, 1 \mathrm{H}, \mathrm{Har}), 7.78(\mathrm{~d}, J=$ $\left.10 \mathrm{~Hz}, 1 \mathrm{H}, \mathrm{H}_{\mathrm{ar}}\right), 7.66-7.63\left(\mathrm{~m}, 1 \mathrm{H}, \mathrm{H}_{\mathrm{ar}}\right), 7.53-7.49\left(\mathrm{~m}, 1 \mathrm{H}, \mathrm{H}_{\mathrm{ar}}\right), 7.27-7.25\left(\mathrm{~m}, 2 \mathrm{H}, \mathrm{H}_{\mathrm{ar}}\right), 7.16-7.13\left(\mathrm{~m}, 9 \mathrm{H}, \mathrm{H}_{\mathrm{ar}}\right), 6.85-$ $6.81\left(\mathrm{~m}, 3 \mathrm{H}, \mathrm{H}_{\mathrm{ar}}, \mathrm{CH} \mathrm{NPE}\right), 6.74\left(\mathrm{~d}, J=10 \mathrm{~Hz}, 2 \mathrm{H}, \mathrm{H}_{\mathrm{ar}}\right), 6.69\left(\mathrm{~d}, J=10 \mathrm{~Hz}, 2 \mathrm{H}, \mathrm{H}_{\mathrm{ar}}\right), 6.36$ (t, $\left.J=10 \mathrm{~Hz}, 1 \mathrm{H}, 1^{\prime}-\mathrm{H}\right)$, $5.31\left(\mathrm{~d}, J=5 \mathrm{~Hz}, 1 \mathrm{H}, 3^{\prime}-\mathrm{OH}\right), 4.85-4.77\left(\mathrm{~m}, 2 \mathrm{H}, \mathrm{CH}_{2} \mathrm{O}\right.$ iPrPac), 4.50-4.48 (m, 1H, 3'- $\left.\mathrm{H}\right), 3.98-3.95\left(\mathrm{~m}, 1 \mathrm{H}, 4^{\prime}-\mathrm{H}\right)$, 3.69-3.67 (m, 6H, 2x OCH $)$, 3.29-3.26 (m, 1H, 5'-H), 3.08-3.05 (m, 1H, 5'-H), 2.90-2.80 (m, 2H, 2'-H, CH iPrPac), 2.35-2.30 (m, 1H, 2'-H), $1.81\left(\mathrm{~d}, J=10 \mathrm{~Hz}, 3 \mathrm{H}, \mathrm{OCHCH}_{3}\right), 1.16\left(\mathrm{~d}, J=5 \mathrm{~Hz}, 6 \mathrm{H}, \mathrm{CH}_{3} \mathrm{PPrPac}\right) \mathrm{ppm}$.

${ }^{13} \mathrm{C}-\mathrm{NMR}(125.8 \mathrm{MHz}$, DMSO-d $): \delta=167.04,158.91,157.90,155.89,152.71,151.17,149.62,147.60,144.95$, $141.93,140.93,137.17,135.59,135.48,134.15,129.63,129.02,127.61,127.13,126.49,124.38,117.82,114.31$, $112.91,86.36,85.28,83.73,70.43,67.30,64.31,54.92,45.70,38.55,32.61,24.11,21.79,11.62$ ppm.

MALDI-HRMS: $m / z$ calcd. for $\mathrm{C}_{50} \mathrm{H}_{50} \mathrm{~N}_{6} \mathrm{O}_{10}[\mathrm{M}+\mathrm{Na}]^{+} 917.34806$, found 917.34811 .

\section{Synthesis of compound 5 :}

$1 \mathrm{~g}$ of compound $4(1.12 \mathrm{mmol}, 1$ eq.) and $950 \mu \mathrm{L}$ (iPr) $2 \mathrm{NEt}(5.59 \mathrm{mmol}, 5$ eq.) were dissolved in $15 \mathrm{~mL}$ dry DCM. $529 \mathrm{mg}$ 2-Cyanoethoxy- $N, N$-diisopropylaminochlorophosphine $(2.23 \mathrm{mmol}, 2$ eq.) were added. The reaction mixture was stirred at room temperature for 1 hour. The solution was diluted with $150 \mathrm{~mL}$ DCM and washed with $150 \mathrm{~mL}$ saturated sodium bicarbonate solution. The aqueous layer was extracted with $100 \mathrm{~mL}$ DCM (2x). The combined organic layers were dried over $\mathrm{MgSO}_{4}$ and evaporated. The residue was purified via column chromatography (cyclohexane/EtOAc $4: 1 \rightarrow 1: 1 \rightarrow 1: 2$ ) to give 5 as a yellowish foam. The column was packed with cyclohexane/EtOAc 4:1 $+0.5 \% \mathrm{Et}_{3} \mathrm{~N}$ while the eluent was prepared without $\mathrm{Et}_{3} \mathrm{~N}$.

Yield: $865 \mathrm{mg}(71 \%)$

1H-NMR (500 MHz, DMSO-d $): \delta=10.15(\mathrm{~d}, J=15 \mathrm{~Hz}, 1 \mathrm{H}, \mathrm{NH}), 8.39\left(\mathrm{~d}, J=5 \mathrm{~Hz}, 1 \mathrm{H}, \mathrm{H}_{\mathrm{ar}}\right), 8.01-8.00\left(\mathrm{~m}, 1 \mathrm{H}, \mathrm{H}_{\mathrm{ar}}\right.$ ), 7.79-7.77 (m, $\left.1 \mathrm{H}, \mathrm{H}_{\mathrm{ar}}\right), 7.68-7.63\left(\mathrm{~m}, 1 \mathrm{H}, \mathrm{H}_{\mathrm{ar}}\right), 7.53-7.49\left(\mathrm{~m}, 1 \mathrm{H}, \mathrm{H}_{\mathrm{ar}}\right), 7.29-7.25\left(\mathrm{~m}, 2 \mathrm{H}, \mathrm{H}_{\mathrm{ar}}\right), 7.17-7.12\left(\mathrm{~m}, 9 \mathrm{H}, \mathrm{H}_{\mathrm{ar}}\right)$, 6.84-6.80 (m, 3H, $\mathrm{H}_{\mathrm{ar}}, \mathrm{CH}$ NPE), 6.76-6.69 (m, 4H, $\mathrm{H}_{\mathrm{ar}}$ ), 6.38-6.35 (m, 1H, 1'-H), 4.85-4.76 (m, 2H, $\mathrm{CH}_{2} \mathrm{O}$ iPrPac), 4.73-4.70 (m, $\left.1 \mathrm{H}, 4^{\prime}-\mathrm{H}\right), 4.10-4.00\left(\mathrm{~m}, 2 \mathrm{H}, 5^{\prime}-\mathrm{H}\right), 3.72-3.66\left(\mathrm{~m}, 7 \mathrm{H}, 2 \mathrm{x} \mathrm{OCH}_{3}, \mathrm{OCH}_{2} \mathrm{CH}_{2} \mathrm{CN}\right), 3.62-3.58(\mathrm{~m}, 1 \mathrm{H}$, 
$\left.\mathrm{OC}_{2} \mathrm{CH}_{2} \mathrm{CN}\right)$, 3.55-3.47 (m, 2H, CH iPr), 3.06-3.02 (m, 1H, 3'- $\left.\mathrm{H}\right), 2.85-2.80(\mathrm{~m}, 1 \mathrm{H}, \mathrm{CH} i \mathrm{Pr}), 2.71(\mathrm{t}, J=5 \mathrm{~Hz}, 1 \mathrm{H}$, $\left.\mathrm{OCH}_{2} \underline{\mathrm{C}}_{2} \mathrm{CN}\right), 2.63-2.57\left(\mathrm{~m}, 1 \mathrm{H}, \mathrm{OCH}_{2} \underline{\mathrm{C}}_{2} \mathrm{CN}\right), 2.55-2.52\left(\mathrm{~m}, 1 \mathrm{H}, 2^{\prime}-\mathrm{H}\right), 2.47-2.43\left(\mathrm{~m}, 1 \mathrm{H}, 2^{\prime}-\mathrm{H}\right), 1.81(\mathrm{~d}, J=10$ $\left.\mathrm{Hz}, 3 \mathrm{H}, \mathrm{OCHCH}_{3}\right), 1.20-1.16\left(\mathrm{~m}, 7 \mathrm{H}, \mathrm{CH}_{3} \mathrm{iPr}\right), 1.11-1.06\left(\mathrm{~m}, 8 \mathrm{H}, \mathrm{CH}_{3} \mathrm{Pr}\right), 0.98\left(\mathrm{~d}, J=5 \mathrm{~Hz}, 3 \mathrm{H}, \mathrm{CH}_{3} \mathrm{iPr}\right) \mathrm{ppm}$.

${ }^{13} \mathrm{C}-N M R(125.8 \mathrm{MHz}$, DMSO-d6): $\delta=167.07,158.95,157.97,157.94,155.89,152.69,152.66,151.21,151.15$, $147.63,147.60,144.83,141.90,140.94,140.91,137.15,137.12,135.45,135.42,135.36,134.16,129.66,129.59$, $129.03,127.60,127.57,127.16,127.09,126.54,124.38,118.98,118.77,117.86,117.82,114.30,112.94,112.89$, $85.48,85.45,85.16,83.86,83.71,73.45,73.30,73.11,72.98,70.39,70.37,67.29,63.69,58.41,58.34,58.26$, $58.20,54.93,42.65,42.55,37.51,37.34,32.61,24.35,24.32,24.29,24.26,24.23,24.16,24.10,21.79,21.76$, $19.80,19.74,19.68$ ppm.

31P-NMR (202.5 MHz, DMSO-d6): $\delta=147.95,147.29$ ppm.

\section{Oligonucleotide synthesis}

Photocaged oligonucleotides were synthesized on an Äkta Oligopilot in $18 \mu \mathrm{mol}$ (S1), $16 \mu \mathrm{mol}$ (S2), $13 \mu \mathrm{mol}$ (S3), $16 \mu \mathrm{mol}$ (S4) and $19 \mu \mathrm{mol}$ (S5) scales. The following reagents were purchased from Sigma Aldrich: DMT-dG-(tac); DMT-dA-(tac)-; DMT-dC-(ac)-; and DMT-dT phosphoramidites and Fast Deprotection Cap 2 containing 4-tertbutylphenoxyacetic anhydride. 5-(Ethylthio)-1H-tetrazole was used as activator. $500 \AA$ DMT-dT-CPG from Glen Research, $500 \AA \AA$ DMT-dC-(tac)-CPG from Millipore, $500 \AA$ CUTAG CPG and $500 \AA$ DMT-dG-(tac)-CPG from Sigma Aldrich were used. All caged oligonucleotides were synthesized DMTr-ON. Deprotection of S1, S2, S4 and S5 was performed using $6.5 \mathrm{~mL} \mathrm{NH}_{4} \mathrm{OH}$ for 1.5 hours at $65^{\circ} \mathrm{C}$ while S3 was deprotected using $6.5 \mathrm{~mL} t-\mathrm{BuNH}_{2}:$ water (1:3) for 4 hours at $60^{\circ} \mathrm{C}$. After deprotection the solvent was evaporated and the crude product purified via RP-HPLC using a MultoKrom $100-5$ C18 column (dimensions: $20 \cdot 250 \mathrm{~mm}$, gradient: $5-40 \% \mathrm{MeCN}$ in $0.1 \mathrm{M}$ TEAA buffer $\mathrm{pH}=7$ in $44 \mathrm{~min}$, flow: $10 \mathrm{~mL} / \mathrm{min}$ ) on an HPLC from Young Lin Instruments with SP930D pumps and a UV730D detector. After evaporation of the solvent, the DMTr group was removed with $80 \%$ HOAc for 20 min at room temperature. The resulting oligonucleotides were purified again via RP-HPLC using the conditions mentioned before.

Table S3. | ESI-MS data of the synthesized oligonucleotides.

\begin{tabular}{|c|c|c|}
\hline Sequence & $\begin{array}{l}\text { Exact Mass cald. } \\
{[\mathrm{Da}]}\end{array}$ & $\begin{array}{l}\text { Mass found } \\
\text { [Da] }\end{array}$ \\
\hline S1: 5'-AGG GT(G $\left.{ }^{(R)-N P E}\right)$ GGG AGG GTG GGT-3' & 5903.0 & 5905.6 \\
\hline S2: 5'-AGG G(G(R)-NPE)A (G(R)-NPE)GG GCT GGG AGG GC-3' & 6664.2 & 6666.9 \\
\hline S3: 5'-AGG GT(G(R)-NPE) GGG AGG GTG GG(G(R)-NPE)-3' & 6077.1 & 6079.7 \\
\hline S4: 5'-A(G(R)-NPE)G GGA GGG $\left(\mathrm{G}^{(R)-\mathrm{NPE}}\right) \mathrm{CT}$ GGG AGG GC-3' & 6664.2 & 6667.9 \\
\hline S5: 5'-AGG GTG GG(G $\left.{ }^{(R)-N P E}\right)$ AGG GTG GGT-3' & 5903.0 & 5906.2 \\
\hline
\end{tabular}




\section{Literature}

(1) Tellinghuisen, J. Statistical Error Propagation. J. Phys. Chem. A 2001, 105 (15), 3917-3921. https://doi.org/10.1021/jp003484u.

(2) Mayer, G.; Kröck, L.; Mikat, V.; Engeser, M.; Heckel, A. Light-Induced Formation of G-Quadruplex DNA Secondary Structures. ChemBioChem 2005, 6 (11), 1966-1970. https://doi.org/10.1002/cbic.200500198.

(3) Helmling, C.; Klötzner, D.-P.; Sochor, F.; Mooney, R. A.; Wacker, A.; Landick, R.; Fürtig, B.; Heckel, A.; Schwalbe, H. Life Times of Metastable States Guide Regulatory Signaling in Transcriptional Riboswitches. Nat. Commun. 2018, 9 (1), 944. https://doi.org/10.1038/s41467-018-03375-w. 